\title{
ANALISIS FAKTOR-FAKTOR YANG MEMPENGARUHI KONSUMSI IKAN PADA WANITA DEWASA DI INDONESIA
}

\section{Analysis of Factors Influencing the Consumption of Fish in Indonesian Women}

\author{
Nurjanah $^{\star 1}$, Taufik Hidayat ${ }^{1}$, Silvia Mawarti Perdana ${ }^{2}$ \\ ${ }^{1}$ Departemen Teknologi Hasil Perairan, Fakultas Perikanan dan Ilmu Kelautan, Institut Pertanian Bogor, \\ Jalan Agatis, Kampus IPB Dramaga Bogor 16680 \\ Telepon 0251-8622915, faks. 0251-8622916. \\ ${ }^{2}$ Departemen Gizi Masyarakat, Fakultas Ekologi Manusia, Institut Pertanian Bogor \\ *Korespondensi: inun_thp10@yahoo.com \\ Diterima 03 Februari 2015/Disetujui 10 April 2015
}

\begin{abstract}
Abstrak
Penelitian ini bertujuan untuk menganalisis konsumsi ikan wanita dewasa Indonesia, hubungannya, dan faktor-faktor lain yang mempengaruhi konsumsi ikan pada wanita dewasa Indonesia. Desain penelitian ini mengacu kepada Riset Kesehatan Dasar (Riskesdas) 2010, yaitu cross sectional, yang dilakukan oleh Badan Penelitian dan Pengembangan Kesehatan Kementerian Kesehatan Republik Indonesia (Balitbangkes Kemenkes RI). Sampel dipilih wanita usia dewasa umur 19-55 tahun. Variabel yang dianalisis meliputi status kerja, perkawina, dan pendidikan. Analisis data menggunakan regresi logistic. Hasil penelitian menunjukkan bahwa ikan menyumbang protein sebesar 19,1 g/hari atau 82\% dari total asupan protein hewani pada wanita dewasa. Konsumsi ikan per hari pada wanita dewasa hanya memenuhi $34 \%$ kebutuhan protein per hari. Terdapat hubungan positif antara konsumsi ikan, asupan lemak, dan status gizi. Status perkawinan dan status ekonomi mempengaruhi konsumsi ikan wanita dewasa, yaitu status perkawinan berpeluang 1,13 kali lebih tinggi mengkonsumsi ikan dibandingkan dengan wanita tidak kawin. Status ekonomi berpeluang untuk menentukan tingkat konsumsi ikan wanita dewasa.
\end{abstract}

Kata kunci: Indeks masa tubuh, konsumsi ikan, wanita dewasa Indonesia

\begin{abstract}
This study aimed to analyze factors affected fish consumption of Indonesian women. This research design was a cross-sectional referred to the Basic Health Research in 2010, conducted by the Health Institute for Research and Development The Ministry of Health Republic of Indonesia. Objects of this study were women within 19-55 years old. The variabel such as nutritional status, social economy and fish consumption were analysed using logistic regression method. The analysis showed that the consumption of fish protein accounted for $19.1 \mathrm{~g} /$ day or $82 \%$ of total animal protein intake in women subjected in this research, however thisconsumption only met $34 \%$ requirement of protein per day. The average of body mass index of the women was $23.2 \pm 4.0 \mathrm{~kg} / \mathrm{m} 2$ and was categorized as normal nutritional status. Positive relationship was found between fish consumption, intake of fat, and nutritional status. The consumption of fish was affected by marital status and economic status. Women with marital status had 1.13 times higher likelihood to consume fish than unmarried women. Economic status also determined fish consumption volume.
\end{abstract}

Keywords: Body mass index, fish consumption, Indonesia women

\section{PENDAHULUAN}

Indonesia merupakan negara maritim yang terbagi atas pulau-pulau dan sebagian wilayahnya merupakan perairan yang cukup luas. Potensi yang cukup luas terdapat di laut
Indonesia berupa sumber daya alam yang melimpah, terdapat banyak spesies ikan, khususnya ikan yang dapat dikonsumsi. Sektor perikanan memiliki peluang yang cukup besar untuk dapat berkembang. 
Indonesia seharusnya dapatmemanfaatkan kekayaan alamnya secara maksimal, termasuk banyak jenis ikan yang baik untuk dikonsumsi penduduk indonesia dan tentunya dapat memenuhi kebutuhan protein penduduk indonesia. Namun, penduduk indonesia memiliki tingkat konsumsi ikan yang masih dikategorikan rendah bahkan di kawasan Asia Tenggara Indonesia, masih rendah dibandingkan Singapura dan Malaysia, apalagi jika dibandingkan dengan Jepang dan Korea. Rendahnya konsumsi ikan perkapita penduduk di indonesia berbanding terbalik dengan wilayahnya yang kaya akan sumber protein hewani ini.

Negara berkembang menghadapi berbagai jenis transisi, salah satunya transisi epidemiologi yang menimbulkan masalah gizi ganda (double burden of communicable and non-communicable diseases) (Kapoor and Anand 2002). Malnutrisi dan infeksi pada awal kehidupan akan meningkatkan risiko chronic noncommunicable diseases (NCDs) di tahap kehidupan selanjutnya. Usia dewasa, kombinasi NCDs dan penyakit infeksi dapat berdampak merugikan (Bygbjerg 2012).

Status gizi pada kelompok dewasa di atas 18 tahun didominasi dengan masalah obesitas, walaupun masalah kurus juga masih cukup tinggi. Angka obesitas pada perempuan cenderung lebih tinggi dibanding laki-laki. Berdasarkan karakteristik, masalah obesitas cenderung lebih tinggi pada penduduk yang tinggal di perkotaan, berpendidikan lebih tinggi dan pada kelompok status ekonomi yang tertinggi pula. Penduduk yang mengkonsumsi protein di bawah kebutuhan minimal (kurang dari $80 \%$ dari angka kecukupan bagi orang Indonesia) adalah sebanyak 37\%. Kontribusi protein terhadap konsumsi energi hanya 13,3\% dan kontribusi konsumsi lemak terhadap energi sebesar 25,6\% (lebih dari anjuran PUGS) (Balitbangkes 2010).

Wanita dewasa perlu mendapat perhatian terhadap penanganan masalah gizi ganda karena berperan penting dalam upaya pencegahan penyakit kronis bagi dirinya dan generasi mendatang. Khusus wanita, hamil pemenuhan gizi secara optimal yang dilakukan ibu selama masa 1000 hari pertama kehidupan (sejak janin dalam kandungan sampai berusia dua tahun), selain memberi kesempatan bagi anak untuk hidup lebih lama, lebih sehat, dan lebih produktif, juga menurunkan risiko anak menderita penyakit degeneratif di usia dewasa. Status gizi dimulai dari wanita dewasa yang berperan penting dalam menyiapkan generasi selanjutnya (Koletzko et al. 2011).

Diet merupakan faktor penting dalam pencegahan penyakit degeneratif (obesitas, diabetes melitus tipe dua, hipertensi, dislipidemia, penyakit jantung koroner, dan stroke) dan pemeliharaan kesehatan (WHO 2002; WHO 2003). Studi yang dilakukan oleh Fung et al. (2004) menunjukkan bahwa pola makanan barat, khususnya tinggi konsumsi daging yang diproses, dapat meningkatkan risiko diabetes melitus tipe dua pada wanita. Terdapat bukti yang cukup kuat, terutama dari studi observasi prospektif, bahwa pola makan yang tinggi konsumsi buah, sayur, dan whole grains; rendah daging dan refined grains; serta asupan sumber lemak yang sehat berperan dalam pencegahan CHD, stroke, dan kanker kolorektal (Schulze \& Hoffmann 2006; Miller et al. 2010).

Sejak tahun 1994, Kementerian Kesehatan RI telah mengeluarkan Pedoman Umum Gizi Seimbang (PUGS). Dewasa ini PUGS belum sepenuhnya diterapkan dalam pola makan atau diet sehari-hari sehingga mengakibatkan masih tingginya masalah gizi ganda, khususnya pada kelompok wanita dewasa, Kemenkes saat ini sedang menyempurnakan Pedoman Gizi Seimbang. Penilaian pemenuhan gizi seimbang pada wanita dewasa, khususnya untuk protein hewani dari ikan, sangat diperlukan sebagai bagian upaya penanganan masalah gizi ganda.

Ikan sebagai sumber pangan memiliki kandungan gizi yang sangat baik misalnya protein sebagai sumber pertumbuhan, asam lemak omega 3 dan 6 yang bermanfaat bagi kesehatan ibu dan pembentukan otak janin, vitamin, serta berbagai mineral yang 
sangat bermanfaat bagi ibu dan janin. Nilai biologisnya mencapai $90 \%$, dengan jaringan pengikat sedikit sehingga lebih mudah dicerna (Nurjanah et al. 2010). Harganya juga jauh lebih murah dibandingkan dengan sumber protein lainnya.

Rendahnya tingkat konsumsi ikan penduduk Indonesia tentunya memiliki beberapa alasan. Penyebab rendahnya tingkat konsumsi ikan adalah terkait dengan masalah mitos dan budaya, sehingga sangat penting dilakukan studi mengenai analisis faktorfaktor yang mempengaruhi konsumsi ikan pada wanita dewasa di Indonesia. Penelitian ini bertujuan untuk menganalisis konsumsi ikan di Indonesia, status gizi wanita dewasa Indonesia, dan faktor lain hubungannya dengan faktorfaktor yang mempengaruhi konsumsi ikan pada wanita dewasa Indonesia.

\section{BAHAN DAN METODE}

\section{Desain, Waktu, dan Tempat}

Datayangdigunakan adalah datasekunder dari Riset Kesehatan Dasar (Riskesdas) tahun 2010, yang dilakukan oleh Badan Penelitian dan Pengembangan Kesehatan (Balitbangkes), Kementerian Kesehatan Republik Indonesia. Desain penelitian Riskesdas 2010 adalah cross sectional. Lokasi penelitian seluruh kabupaten/kota dari 33 propinsi. Penelitian ini dilakukan pada bulan Juni-Oktober 2014 di Kampus IPB Darmaga, Bogor, Jawa Barat.

\section{Jumlah dan Cara Penarikan Subyek}

Jumlah dan cara pengambilan subyek penelitian mengikuti jumlah dan cara pengambilan subyek Riskesdas 2010. Subyek Riskesdas 2010 di tingkat kabupaten/ kota berasal dari 441 kabupaten/kota yang tersebar di 33 provinsi.

Populasi dalam Riskesdas 2010 adalah seluruh rumah tangga yang mewakili 33 provinsi di Indonesia. Proses pemilihan rumah tangga dilakukan oleh Badan Pusat Statistik (BPS) dengan two stage sampling. Riskesdas memilih blok sensus yang telah dikumpulkan pada sensus penduduk. Pemilihan blok sensus tersebut dilakukan sepenuhnya oleh BPS dengan memperhatikan status ekonomi dan rasio perkotaan/perdesaan. Blok sensus tersebut proporsional terhadap jumlah rumah tangga di kabupaten/kota tersebut. Blok sensus yang dipilih untuk kesehatan masyarakat adalah sebesar 2.800 blok sensus dengan 70000 rumah tangga.

Riskesdas 2010 berhasil mengunjungi 2798 blok sensus dari 441 kabupaten/kota. Jumlah rumah tangga dari blok sensus tersebut sebanyak 69300 rumah tangga dengan jumlah anggota rumah tangga sebanyak 251.388 orang. Dari 441 kabupaten/ kota tersebut didapatkan 68486 orang wanita dewasa usia 19-55 tahun. Kriteria inklusi meliputi wanita berusia 19-55 tahun. Kriteria eksklusi meliputi wanita yang hamil dan memiliki kondisi konsumsi tidak biasa (hajatan, hari raya, puasa, sakit, dan diet) pada saat dilakukan survey konsumsi. Cleaning data dilakukan untuk subyek yang tidak memiliki data berat badan, tinggi badan, status kehamilan, dan konsumsi pangan; IMT $<13$ dan $>40$; asupan energi $<0,3$ atau $>3$ kali dari energi basal; serta memiliki tingkat kecukupan zat gizi $>400 \%$.

\section{Jenis dan Cara Pengumpulan Data}

Data yang digunakan dalam penelitian ini seluruhnya data sekunder termasuk pengumpulan data. Cara pengumpulan data terdapat pada Tabel 1 .

\section{Pengolahan dan Analisis Data}

Pengolahan dan analisis data dilakukan menggunakan program komputer. Proses cleaning dilakukan untuk memastikan data yang digunakan logis dan sesuai dengan variabel yang ditentukan. Analisis karakteristik subyek secara deskriptif, korelasi antara pola konsumsi ikan dan status gizi pada wanita dewasa Indonesia dilakukan dengan menggunakan korelasi pearson. Analisis faktor-faktor dilakukan dengan regresi logistik. 
Tabel 1 Jenis dan cara pengumpulan data

\begin{tabular}{|c|c|c|c|}
\hline No & Peubah & Keterangan & Cara pengumpulan data \\
\hline & Karakteristik Subjek & Kuesioner Riskesdas & \multirow{5}{*}{ Wawancara } \\
\hline 1 & Daerah & & \\
\hline 2 & Status perkawinan & & \\
\hline 3 & Usia & & \\
\hline 4 & Status hamil & & \\
\hline & Karakteristik Sosial Ekonomi & Kuesioner Riskesdas & \multirow{4}{*}{ Wawancara } \\
\hline 1 & Pendidikan & & \\
\hline 2 & Pekerjaan & & \\
\hline 3 & Status ekonomi & & \\
\hline & Antropemetri & Kuesioner Riskesdas & Pengukuran Langsung \\
\hline 1 & Berat badan & Blok X No 1a,1b & $\begin{array}{l}\text { Diukur dengan timbangan } \\
\text { berat badan digital (kapasitas } \\
150 \mathrm{~kg} \text { dan ketelitian } 50 \mathrm{~g} \text { ) }\end{array}$ \\
\hline \multirow[t]{2}{*}{2} & Tinggi badan & Blok X No 2a, 2b & $\begin{array}{l}\text { Diukur dengan alat ukur tinggi } \\
\text { badan multi fungsi (kapasitas } \\
\text { ukur } 2 \mathrm{~m} \text { dan ketelitian } 0,1 \mathrm{~cm} \text { ) }\end{array}$ \\
\hline & Konsumsi Pangan & Kuesioner Riskesdas & \\
\hline 1 & Jumlah pangan & Blok XI & Food recall 1x24 jam \\
\hline 2 & Jenis pangan & Blok XI & \\
\hline
\end{tabular}

\section{Pengelompokan Subyek untuk Analisis}

Daerah tempat tinggal subyek dikelompokkan menjadi perkotaan dan perdesaan. Status perkawinan dikelompokkan menjadi kawin dan tidak kawin. Usia dikelompokkan menjadi tiga kelompok, yaitu: 19-29 tahun, 30-49 tahun, dan 50-55 tahun. Status hamil dikelompokkan menjadi hamil dan tidak hamil. Pendidikan subyek dikelompokkan menjadi tiga kelompok, yaitu: tidak tamat/tamat SD/MI, tamat SLTP/ MTS, dan tamat SMA/MA/PT (Perguruan Tinggi). Pekerjaan subyek dikelompokkan menjadi enam kelompok, yaitu: tidak bekerja, sekolah, TNI/Polri/PNS/Pegawai, wiraswasta/ layanan jasa/dagang, petani/nelayan/buruh, dan lainnya. Status ekonomi dikelompokkan menurut kuintil yang didasarkan pada besar pengeluaran keluarga per kapita setiap bulannya.

Data status gizi merupakan hasil olahan dari data berat badan dan tinggi badan dengan menggunakan rumus :

$$
\mathrm{IMT}=\mathrm{BB}(\mathrm{kg}) /(\mathrm{TB}(\mathrm{m}) \mathrm{xTB}(\mathrm{m}))
$$

Kurus $=<50$, normal $=50-60$; gemuk $=>70$

Konsumsi ikan mengukur jumlah ikan yang dikonsumsi relatif terhadap jumlah konsumsi ikan yang dianjurkan sesuai pedoman gizi seimbang. Anjuran jumlah porsi kelompok pangan hewani pada wanita dewasa Indonesia mengacu pada panduan Pedoman Gizi Seimbang (PGS) yang dikeluarkan oleh Kemenkes RI (2014), dengan jumlah anjuran yaitu: tiga porsi.

Konsumsi ikan akan dikonversikan dalam protein dengan menggunakan Daftar Komposisi Bahan Makanan. Angka kecukupan protein ikan diperoleh dengan membandingkan asupan protein dari ikan dibandingkan dengan Angka Kecukupan Protein yang direkomendasikan di Indonesia (Permenkes 2013). 


\section{HASIL DAN PEMBAHASAN}

\section{Karakteristik Sosial Ekonomi}

Subyek dalam studi ini adalah wanita dewasa berjumlah 61759 orang dengan rentang usia 19-55 tahun. Rentang usia subyek dikelompokkan menjadi 19-29 tahun (20028 orang), 30-49 tahun (35684 orang), dan 5055 tahun (6047 orang). Karakteristik sosial ekonomi subyek terdiri dari status perkawinan, status pendidikan, status pekerjaan, status ekonomi, dan daerah tempat tinggal. Sebaran subyek berdasarkan karakteristik sosial ekonomi dapat dilihat pada Tabel 2.

Subyek sebagian besar memiliki status perkawinan $(86,7 \%)$ dengan persentase kelompok usia 50-55 tahun (98,3\%) tertinggi dibandingkan kelompok usia 19-29 tahun (66,6\%) dan kelompokusia30-49 tahun(96,0\%). Berdasarkan latar belakang pendidikan, subyek dapat dikelompokkan menjadi tidak tamat/

Tabel 2 Sebaran subyek berdasarkan karakteristik sosial ekonomi

\begin{tabular}{|c|c|c|c|c|c|c|c|c|c|}
\hline \multirow{3}{*}{ No } & \multirow{3}{*}{ Karakteristik } & \multicolumn{6}{|c|}{ Kelompok usia } & \multirow{2}{*}{\multicolumn{2}{|c|}{ Total }} \\
\hline & & \multicolumn{2}{|c|}{ 19-29 Tahun } & \multicolumn{2}{|c|}{ 30-49 tahun } & \multicolumn{2}{|c|}{ 50-55 tahun } & & \\
\hline & & $\mathrm{n}$ & $\%$ & $\mathrm{n}$ & $\%$ & $\mathrm{~N}$ & $\%$ & $\mathrm{n}$ & $\%$ \\
\hline \multirow[t]{4}{*}{1} & Status Perkawinan & & & & & & & & \\
\hline & Kawin & 13339 & 66,6 & 34260 & 96,0 & 5944 & 98,3 & 53543 & 86,7 \\
\hline & Tidak Kawin & 6689 & 33,4 & 1424 & 4,0 & 103 & 1,7 & 8216 & 13,3 \\
\hline & & 20028 & 100,0 & 35684 & 10 & 6047 & 100,0 & 61759 & 100 \\
\hline \multirow[t]{5}{*}{2} & Status Pendidikan & & & & & & & & \\
\hline & Tidak tamat/Tamat SD/MI & 6407 & 32,0 & 19660 & 55,1 & 4687 & 77,5 & 30754 & 49,8 \\
\hline & Tamat SMP/MTS & 4729 & 23,6 & 5660 & 15,9 & 576 & 9,5 & 10965 & 17,8 \\
\hline & Tamat SMA/MA/PT & 8892 & 44,4 & 10364 & 29,0 & 784 & 13,0 & 20040 & 32,4 \\
\hline & & 20028 & 100,0 & 35684 & 100 & 6047 & 100,0 & 61759 & 100 \\
\hline \multirow[t]{8}{*}{3} & Status Pekerjaan & & & & & & & & \\
\hline & Tidak Bekerja/Sekolah & 10271 & 51,3 & 14712 & 41,2 & 2280 & 37,7 & 27263 & 44,1 \\
\hline & Pegawai Negeri & 1359 & 6,8 & 2536 & 7,1 & 325 & 5,4 & 4220 & 6,8 \\
\hline & Wiraswasta/Profesional & 2985 & 14,9 & 5959 & 16,7 & 930 & 15,4 & 9874 & 15,9 \\
\hline & Petani/Nelayan & 2194 & 11,0 & 6941 & 19,5 & 1645 & 27,2 & 10780 & 17,5 \\
\hline & Buruh & 1423 & 7,1 & 2457 & 6,9 & 389 & 6,4 & 4269 & 6,9 \\
\hline & Lainnya & 1796 & 8,9 & 3079 & 8,7 & 478 & 7,9 & 5353 & 8,8 \\
\hline & & 20028 & 100,0 & 35684 & 100,0 & 6047 & 100 & 61759 & 100,0 \\
\hline \multirow[t]{7}{*}{4} & Status Ekonomi & & & & & & & & \\
\hline & Kuintil 1 & 4231 & 21,1 & 7598 & 21,3 & 1192 & 19,7 & 13021 & 21,1 \\
\hline & Kuintil 2 & 4057 & 20,3 & 7521 & 21,1 & 1185 & 19,5 & 12763 & 20,7 \\
\hline & Kuintil 3 & 4160 & 20,8 & 7160 & 20,1 & 1234 & 20,5 & 12554 & 20,3 \\
\hline & Kuintil 4 & 3987 & 19,9 & 6999 & 19,5 & 1232 & 20,4 & 12218 & 19,8 \\
\hline & Kuintil 5 & 3593 & 17,9 & 6406 & 18,0 & 1204 & 19,9 & 11203 & 18,1 \\
\hline & & 20028 & 100,0 & 35684 & 100,0 & 6047 & 100,0 & 61759 & 100,0 \\
\hline \multirow[t]{4}{*}{5} & Daerah & & & & & & & & \\
\hline & Perkotaan & 10604 & 52,9 & 18490 & 51,8 & 3060 & 50,6 & 32154 & 52,1 \\
\hline & Perdesaan & 9424 & 47,1 & 17194 & 48,2 & 2987 & 49,4 & 29605 & 47,9 \\
\hline & & 20028 & 100,0 & 35684 & 100,0 & 6047 & 100,0 & 61759 & 100,0 \\
\hline
\end{tabular}


tamat SD/MI, tamat SLTP/MTS, dan tamat SLTA/MA/PT. Persentase tertinggi untuk semua kelompok usia adalah tidak tamat/tamat SD/MI (49,8\%), begitu pula untuk kelompok usia 30-49 tahun $(55,1 \%)$ dan 50-55 tahun (77,5\%). Persentase tertinggi untuk kelompok usia 19-29 tahun adalah tamat SLTA/MA/PT $(44,4 \%)$.

Status pekerjaan, subyek dikelompokkan menjadi tidak bekerja/sekolah, pegawai negeri, wiraswasta/profesional, petani/nelayan, buruh, dan lainnya. Hampir sebagian wanita dewasa berusia 19-55 tahun tidak bekerja/sekolah $(44,1 \%)$. Status ekonomi subyek berdasarkan Riskesdas 2010 dibagi menjadi lima kelompok, yaitu: kuintil 1, kuintil 2, kuintil 3, kuintil 4, dan kuintil 5. Jumlah subyek terbanyak berasal dari kuintil $1(21,1 \%)$, sama halnya dengan kelompok usia 19-29 tahun (21,1\%) dan 30-49 tahun (21,3\%). Kelompok usia 5055 tahun memiliki persentase tertinggi pada kuintil 3 sebesar 20,5\%. Karakteristik daerah atau tempat tinggal dibedakan menjadi daerah perkotaan dan perdesaan. Semua kelompok usia sebagian besar $(52,1 \%)$ bertempat tinggal di daerah perkotaan.

\section{Pola Konsumsi Ikan}

Ikan memiliki kontribusi terhadap pemenuhan zat gizi dari pangan hewani. Tabel 3 memperlihatkan konsumsi ikan pada wanita dewasa sebesar 109 g. Pedoman Gizi Seimbang (2014) menganjurkan wanita dewasa mengkonsumsi 120 gram pangan hewani sebagai penyumbang protein dengan mutu gizi yang tinggi. Pemenuhan pangan hewani dari ikan sesuai pedoman gizi seimbang adalah $91 \%$ atau hampir memenuhi anjuran konsumsi. Ikan menyumbang protein sebanyak $19,1 \mathrm{~g} /$ hari atau $82 \%$ dari total asupan protein pangan hewani. Jika dibandingkan dengan kebutuhan protein, konsumsi ikan perhari pada wanita dewasa hanya memenuhi $34 \%$ kebutuhan protein per hari. Pola konsumsi ikan tidak terdapat perbedaan yang signifikan antar kelompok umur pada wanita dewasa di Indonesia.

Tabel 3 Konsumsi ikan pada wanita dewasa di Indonesia

\begin{tabular}{|c|c|c|c|c|c|}
\hline \multirow{2}{*}{ No } & \multirow{2}{*}{ Komponen } & \multicolumn{3}{|c|}{ Kelompok usia } & \multirow{2}{*}{ Total } \\
\hline & & 19-29 tahun & 30-49 tahun & 50-55 tahun & \\
\hline 1 & Jumlah konsumsi ikan /hari & $108 \pm 83$ & $110 \pm 81$ & $107 \pm 80$ & $109 \pm 82$ \\
\hline 2 & $\begin{array}{l}\text { Anjuran konsumsi pangan } \\
\text { hewani sesuai PGS (g/hari) }\end{array}$ & \multicolumn{4}{|c|}{120} \\
\hline 3 & $\begin{array}{l}\text { Pemenuhan pangan hewani } \\
\text { sesuai PGS (\%) }\end{array}$ & $90 \pm 69$ & $91 \pm 68$ & $89 \pm 66$ & $91 \pm 68$ \\
\hline 4 & $\begin{array}{l}\text { Asupan protein dari ikan } \\
\text { (g/hari) }\end{array}$ & $19,0 \pm 14,5$ & $19,2 \pm 14,2$ & $18,8 \pm 13,9$ & $19,1 \pm 14,3$ \\
\hline 5 & $\begin{array}{l}\text { Total asupan protein dari } \\
\text { pangan hewani (g/hari) }\end{array}$ & $23,7 \pm 16,7$ & $23,4 \pm 16,1$ & $22,3 \pm 15,7$ & $23,4 \pm 16,3$ \\
\hline 6 & $\begin{array}{l}\text { Presentasi asupan protein } \\
\text { ikan dibandingkan total } \\
\text { asupan protein pangan } \\
\text { hewani }(\%)\end{array}$ & $80 \pm 77$ & $82 \pm 78$ & $84 \pm 79$ & $82 \pm 77$ \\
\hline 7 & Kebutuhan protein (g/hari) & $52,9 \pm 9,2$ & $57,3 \pm 10,4$ & $56,2 \pm 11,1$ & $55,8 \pm 10,3$ \\
\hline 8 & $\begin{array}{l}\text { Kontribusi asupan protein } \\
\text { ikan terhadap kebutuhan } \\
\text { protein }(\%)\end{array}$ & $36 \pm 22$ & $34 \pm 23$ & $33 \pm 14$ & $34 \pm 13$ \\
\hline 9 & $\begin{array}{l}\text { Angka kecukupan protein } \\
(\mathrm{AKP})(\mathrm{g})\end{array}$ & 62 & 65 & 65 & $64 \pm 1,73$ \\
\hline
\end{tabular}




\section{Hubungan antara Konsumsi Ikan, Asupan Zat Gizi, dan Status Gizi}

Data berat badan dan tinggi badan dikalkulasikan dengan menggunakan rumus perhitungan untuk menentukan IMT (Indeks Massa Tubuh). Nilai IMT yang diperoleh kemudian diklasifikasikan berdasarkan WHO (2007) menjadi status gizi kurang, normal, dan gemuk. Nilai rata-rata berat badan wanita dewasa adalah $53,6 \pm 9,9 \mathrm{~kg}$. Sementara itu, rata-rata tinggi badan subyek secara keseluruhan adalah sebesar 152,2 $\pm 6,2$ $\mathrm{cm}$. Wanita dewasa memiliki rata-rata indeks massa tubuh (IMT), yaitu sebesar 23,2 $\pm 4,0$ $\mathrm{kg} / \mathrm{m}^{2}$ yang dikategorikan sebagai status gizi normal.

Sebaran subyek berdasarkan status gizi tersaji pada Tabel 4. Secara keseluruhan, subyek memiliki status gizi normal dengan persentase sebanyak $61,5 \%$. Sebagian besar subyek dari masing-masing kelompok usia memiliki status gizi normal, masing-masing sebanyak $69,1 \%, 58,5 \%$, dan $55,0 \%$. Persentase paling kecil adalah status gizi kurang yaitu sebanyak 9,5\%. Hasil studi juga menunjukkan bahwa terdapat $29,0 \%$ subyek yang mengalami kegemukan.

Tabel 5 memperlihatkan bahwa terdapat hubungan antara konsumsi ikan, asupan, zat gizi, dan status gizi. konsumsi ikan berhubungan positif dengan asupan energi dan beberapa zat gizi, antara lain: lemak, lemak jenuh, kolesterol, lemak trans, dan natrium. Selain itu, konsumsi ikan dan asupan zat gizi juga berhubungan positif dengan indeks massa tubuh yang melambangkan status gizi.

\section{Faktor-faktor yang Mempengaruhi Konsumsi Ikan}

Terdapat beberapa faktor yang mempengaruhi konsumsi ikan. Faktor-faktor tersebut adalah status perkawinan dan status ekonomi. Tabel 6 menunjukkan hasil uji logistic regression untuk konsumsi ikan. Wanita

Tabel 4 Sebaran status gizi subyek berdasarkan kelompok usia

\begin{tabular}{|c|c|c|c|c|c|c|c|c|c|}
\hline \multirow{3}{*}{ No } & \multirow{3}{*}{ Status gizi } & \multicolumn{6}{|c|}{ Kelompok usia } & \multirow{2}{*}{\multicolumn{2}{|c|}{ Total }} \\
\hline & & \multicolumn{2}{|c|}{ 19-29 tahun } & \multicolumn{2}{|c|}{ 30-49 tahun } & \multicolumn{2}{|c|}{ 50-55 tahun } & & \\
\hline & & $\mathrm{n}$ & $\%$ & $\mathrm{n}$ & $\%$ & $\mathrm{n}$ & $\%$ & $\mathrm{~N}$ & $\%$ \\
\hline 1 & Kurus & 2876 & 14,4 & 2391 & 6,7 & 575 & 9,5 & 5842 & 9,5 \\
\hline 2 & Normal & 13832 & 69,1 & 20866 & 58,5 & 3326 & 55,0 & 38024 & 61,5 \\
\hline \multirow[t]{2}{*}{3} & Gemuk & 3320 & 16,5 & 12427 & 34,8 & 2146 & 35,5 & 17893 & 29,0 \\
\hline & & 20028 & 100,0 & 35684 & 100.0 & 6047 & 100,0 & 61759 & 100,0 \\
\hline
\end{tabular}

Tabel 5 Uji korelasi Pearson hubungan antara konsumsi ikan, asupan zat gizi, dan status gizi

\begin{tabular}{lcccccccc}
\hline \multicolumn{1}{c}{ Variabel } & IMT & Energi & Lemak & $\begin{array}{c}\text { Lemak } \\
\text { jenuh }\end{array}$ & Kolesterol & $\begin{array}{c}\text { Lemak } \\
\text { trans }\end{array}$ & Natrium & $\begin{array}{c}\text { Konsumsi } \\
\text { ikan }\end{array}$ \\
\hline IMT & 1 & 0,05 & 0,05 & 0,05 & 0,02 & 0,03 & 0,02 & 0,02 \\
Energi & 0,05 & 1 & 0,80 & 0,71 & 0,44 & 0,24 & 0,63 & 0,31 \\
Lemak & 0,05 & 0,80 & 1 & 0,84 & 0,36 & 0,20 & 0,52 & 0,28 \\
Lemak jenuh & 0,05 & 0,71 & 0,84 & 1 & 0,34 & 0,29 & 0,46 & 0,27 \\
Kolestrol & 0,02 & 0,44 & 0,36 & 0,34 & 1 & 0,06 & 0,52 & 0,29 \\
Lemak trans & 0,03 & 0,24 & 0,20 & 0,29 & 0,06 & 1 & 0,05 & 0,03 \\
Natrium & 0,02 & 0,63 & 0,52 & 0,46 & 0,52 & 0,05 & 1 & 0,16 \\
Konsumsi & 0,02 & 0,31 & 0,28 & 0,27 & 0,29 & 0,03 & 0,16 & 1 \\
ikan & & & & & & & & \\
\hline
\end{tabular}

Keterangan: nilai koefisien korelasi di atas signifikan dengan nilai $p<0,01$ 
Tabel 6 Hasil uji regresi logistik faktor-faktor yang mempengaruhi konsumsi ikan pada wanita dewasa Indonesia

\begin{tabular}{|c|c|c|c|c|c|}
\hline Variabel & Kategori & B & Sig. & OR $\operatorname{Exp}(B)$ & $\begin{array}{c}95.0 \% \text { CI for } \\
\operatorname{Exp}(B)\end{array}$ \\
\hline $\mathrm{X}_{1}=$ Daerah & $\begin{array}{l}0=\text { Perdesaan } \\
1=\text { Perkotaan }\end{array}$ &,- 023 & ,261 & ,978 & $0,940-1,017$ \\
\hline $\mathrm{X}_{2}=$ Status kawin & $\begin{array}{l}0=\text { Tidak kawin } \\
1=\text { Kawin }\end{array}$ &, 122 &, $000^{*}$ & 1,129 & $1,059-1,204$ \\
\hline $\mathrm{X}_{3}=$ Status ekonomi & $\begin{array}{l}0=\text { Kuintil 1-2 } \\
1=\text { Kuintil 3-4 }\end{array}$ &, 110 &, $000^{*}$ & 1,116 & $1,063-1,172$ \\
\hline $\mathrm{X}_{4}=$ Pendidikan & $\begin{array}{l}0=\text { Tidak tamat } / \text { ta- } \\
\text { mat SD } / \text { tamat } S M P \\
1=\text { Tamat SMA } / \mathrm{PT}\end{array}$ & ,006 &, $822^{*}$ & 1,006 & ,954-1,061 \\
\hline$X_{5}=$ Pekerjaan & $\begin{array}{l}0=\text { Tidak bekerja/ } \\
\text { sekolah/petani/ne- } \\
\text { layan/buruh } \\
1=\text { Pegawai negeri/ } \\
\text { wiraswasta/lainnya }\end{array}$ &, 028 &, $287^{*}$ & 1,028 & ,977-1,082 \\
\hline $\mathrm{X}_{6}=\mathrm{Usia}$ & $\begin{array}{l}0=19-29 \text { tahun } \\
1=30-49 \text { tahun } \\
/ 50-55 \text { tahun }\end{array}$ & ,046 &, $082^{*}$ & 1,047 & ,994-1,103 \\
\hline \multicolumn{2}{|c|}{ Konstanta } &,- 963 & ,000 & ,382 & \\
\hline
\end{tabular}

dewasa dengan status perkawinan memiliki peluang 1,13 kali lebih tinggi mengkonsumsi ikan dibandingkan wanita yang tidak kawin. Louzada et al. (2012) menyatakan bahwa bahwa individu yang menikah memiliki kualitas diet yang lebih baik.

Wanita dewasa dengan status ekonomi menengah hingga tinggi (kuintil 3, 4, dan 5) berpeluang 1,11 kali mengkonsumsi ikan yang lebih tinggi dibandingkan status ekonomi rendah (kuintil 1 dan 2). Penelitian McCabe-Sellers et al. (2007) menunjukkan bahwa faktor sosial ekonomi mempengaruhi kualitas diet orang dewasa di Amerika. Hasil studi di atas menunjukkan bahwa karakteristik sosial demografi mempengaruhi pemilihan makanan dan keseluruhan kualitas diet (Ervin 2011).

\section{KESIMPULAN}

Pemenuhan pangan hewani dari ikan sesuai pedoman gizi seimbang adalah $91 \%$ atau hampir memenuhi anjuran konsumsi. Ikan menyumbang protein sebanyak $19,1 \mathrm{~g}$ per hari atau $82 \%$ dari total asupan protein pangan hewani. Kebutuhan protein, konsumsi ikan perhari pada wanita dewasa hanya memenuhi $34 \%$ kebutuhan protein per hari. Tidak terdapat perbedaan pola konsumsi ikan yang signifikan antar kelompok umur pada wanita dewasa di Indonesia.

Wanita dewasa memiliki rata-rata indeks massa tubuh (IMT), yaitu sebesar 23,2 $\pm 4,0 \mathrm{~kg} /$ $\mathrm{m}^{2}$ yang dikategorikan sebagai status gizi normal. Subyek secara keseluruhan memiliki status gizi normal dengan persentase sebanyak $61,5 \%$. Subyek dari masing-masing kelompok usia memiliki status gizi normal, masing-masing sebanyak $69,1 \%$, 58,5\%, dan $55,0 \%$. Persentase status gizi paling rendah sebesar 9,5\%. Hasil studi juga menunjukkan bahwa terdapat 29,0\% subyek yang mengalami kegemukan.

Terdapat hubungan antara konsumsi ikan, asupan, zat gizi, dan status gizi. konsumsi ikan berhubungan positif dengan asupan energi dan beberapa zat gizi, antara lain: lemak, lemak jenuh, kolesterol, lemak trans, dan natrium. Konsumsi ikan berhubungan positif dengan indeks massa tubuh. 
Status perkawinan dan status ekonomi mempengaruhi konsumsi ikan. Wanita dewasa dengan status perkawinan memiliki peluang 1,13 kali lebih tinggi mengkonsumsi ikan dibandingkan wanita yang tidak kawin. Wanita dewasa dengan status ekonomi menengah hingga tinggi (kuintil 3, 4, dan 5) berpeluang 1,11 kali mengkonsumsi ikan yang lebih tinggi dibandingkan status ekonomi rendah (kuintil 1 dan 2).

\section{UCAPAN TERIMA KASIH}

Terima kasih kepada Program Analisis Lanjut Balai Penelitian dan Pengembangan Kesehatan Kementerian Kesehatan Republik Indonesia dan Pusdatin, Seketariat Jenderal Kementerian Kelautan dan Perikanan Republik Indonesia yang telah membantu penyelesaian riset ini.

\section{DAFTAR PUSTAKA}

[Balitbangkes] Badan Penelitian dan Pengembangan Kesehatan Kementerian Kesehatan RI. 2007. Riset Kesehatan Dasar (Riskesdas) 2007. Jakarta: Kemenkes RI. . 2010. Riset Kesehatan Dasar

(Riskesdas) 2010. Jakarta: Kemenkes RI. . 2013. Riset Kesehatan Dasar (Riskesdas) 2013. Jakarta: Kemenkes RI.

Bygbjerg IC. 2012. Double burden of noncommunicable and infectious diseases in developing countries. Science 337(6101):1499-1501.doi:10.1126/ science.1223466.

[Depkes] Departemen Kesehatan Republik Indonesia Direktorat Bina Gizi Masyarakat. 2014. Pedoman Gizi Seimbang (PGS) [Internet]. [diunduh 2014 Oktober 23].

Ervin RB. 2011. Healthy Eating Index-2005 Total and Component Scores for Adults Aged 20 and Over: National Health and Nutrition Examination Survey, 2003-2004. National Health Statistic Reports 44:1-10.

Fung TT, Schulze M, Manson JE, Willett WC, Hu FB. 2004. Dietary patterns, meat intake, and the risk of type 2 diabetes in women. Arch Intern Med. 164(20):223540. 15534160 [PubMed-indexed for MEDLINE].

Kapoor SK, Anand K. 2002. Nutritional transition: a public health challenge in developing countries [editorial]. Journal Epidemiol Community Health 56:804-805.

Koletzko B, Brands B, Demmelmair H. 2011. The Early Nutrition Programming Project (Earnest):5yof successfulmultidisciplinary collaborative research. Am Journal Clin Nutrition 94 (suppl):1749s-53s.

Louzada MD, Durgante PC, DeMarchi RJ, Hugo FN, Hilgert JB, Padilha DP, Antunes MT. 2012. Healthy eating index in Southern Brazilian older adults and its association with socioeconomic, behavioral and health characteristics. The Journal of Nutrition, Health and Aging 16(1).

McCabe-Sellers BJ, Bowman S, Stuff JE, Champagne CM, Simpson PM, Bogle ML. 2007. Assessment of the diet quality of US adults in the Lower Mississippi Delta. Journal Clin Nutrition 86:697-706.

Nurjanah, Suwandi R, Yogaswari V. 2010. Karakteristik kimia dan fisik sisik ikan gurami (Osphronemus gouramy). Jurnal Sumberdaya Perairan 4(2):7-12.

Miller PE, Lazarus P, Lesko SM, Muscat JE, Harper G, Cross AJ, Sinha R, Ryczak K, Escobar G, Mauger DT, Hartman TJ. 2010. Diet index-based and empirically derived dietary patterns are associated with colorectal cancer risk. Journal Nutrition doi: 10.3945/jn.110.121780.

[PERMENKES]. 2013. Angka Kecukupan Gizi yang Dianjurkan Bagi Bangsa Indonesia. Jakarta : Kemenkes RI.

[WHO] World Health Organization. 1998. Life in the 21st century: a vision for all. Geneva: World Health Organization. 2002. Reducing Risks, Promoting Healthy Life. Geneva: World Health Organization. 2003. Diet, Nutrition and the Prevention of Chronic Diseases. Geneva: World Health Organization.

2007. Obesity and Overweight. Global Strategy on Diet. Physical Activity and Health. Available at: http://www.who.int/dietphysicalactivity Accessed April 2010.

Masyarakat Pengolahan Hasil Perikanan Indonesia 